\title{
Folates in lettuce: a pilot study
}

\author{
Madelene Johansson', Margaretha Jägerstad ${ }^{2}$ and \\ Wenche Frolich'
}

'Norwegian School of Hotel Management, University of Stavanger, Stavanger, Norway; ${ }^{2}$ Department of Food Science, Swedish University of Agricultural Science, Uppsala, Sweden

Abstract

Background: Leafy vegetables are good sources of folates and food shops nowadays offer an increasing number of lettuce varieties.

Objective: To obtain data on the folate content and forms in common lettuce varieties and spinach sold in the Nordic countries, and to investigate effects of different storage conditions and preparations in the consumer's home or at lunchtime restaurants.

Design: Folate was analysed in eight different lettuce varieties and spinach using a validated highperformance liquid chromatographic method and the detected forms of folates were confirmed by a mass spectrometric detector [liquid chromatography-mass spectrometry (LC-MS)] following heat extraction, deconjugation with rat serum and purification by solid-phase extraction.

Results : Folate content, expressed in folic acid equivalents, in the lettuce samples varied six-fold, from 30 to $198 \mu \mathrm{g} 100 \mathrm{~g}^{-1}$ on a fresh weight basis. The folate content was decreased by $14 \%$ after storage at $4^{\circ} \mathrm{C}$ for 8 days and by $2-40 \%$ after storage at $22^{\circ} \mathrm{C}$ for $2-4 \mathrm{~h}$, depending on whether samples were stored as whole leaves, or small torn or cut pieces. LC-MS confirmed the identity of the folate forms: $\mathrm{H}_{4}$ folate, $5-\mathrm{CH}_{3}-$ $\mathrm{H}_{4}$ folate, 5- $\mathrm{HCO}-\mathrm{H}_{4}$ folate and $10-\mathrm{HCO}-\mathrm{H}_{4}$ folate.

Conclusion: The considerable variation in folate content between varieties of lettuce in this pilot study, with one variety reaching the level found in spinach, indicates the potential to increase folate intake considerably by choosing folate-rich varieties of lettuce and storing at low temperatures.

Keywords: folate analysis; folate retention; HPLC, LC-MS; leafy vegetables; storage

Received: 5 Dec. 2006; Revised: I Feb. 2007; Accepted: 15 Feb. 2007

\section{Introduction}

$\mathrm{L}$ eafy vegetables are common food items in a well-balanced diet, and increased consumption of fruit and vegetables is a general goal in public health work in Western countries. In a recent survey green salad was the third most popular vegetable in Sweden and Åland, fourth most popular in Finland and Denmark, and sixth most popular in Norway (1). Most lettuce varieties offered in Scandinavian food shops today derive from the four genera Lactuca (e.g. iceberg lettuce, oakleaf lettuce), Chicorium (e.g. frillice lettuce), Eruca (e.g. rocket) and Valerianella (e.g. manche).

Adequate intake of folate is an important factor in the prevention of neural tube defects and may be a factor in decreasing the risk of chronic diseases (2-5). The average daily intake of folate in the Nordic population, especially among fertile woman, is lower $\left(\sim 200 \mu \mathrm{g}\right.$ folate day $\left.{ }^{-1}\right)$ than recommended $\left(400 \mu \mathrm{g}\right.$ folate $\left.\mathrm{day}^{-1}\right)$ (3). In a review (6), plant foods (vegetables, fruit and potatoes) were stated to be predominant contributors to folate intake in Europe. Even in countries from Northern Europe, where plant food consumption is lower than in the various Mediterranean diets, plant foods are estimated to contribute approximately $40 \%$ of the total folate intake among adults (6). Despite the importance of folate in human nutrition, data on folate content in different vegetables, including lettuce varieties, are limited.

Multiple forms of folates with different susceptibility to degradation during storage exist in plant foods, and the precise distribution of these different forms depends not only on the species, but also on growth, harvest and postharvest conditions. The effect of different storage conditions on the folate concentrations in spinach was studied by Chen et al. (7), who found that the content of folate was reduced by $7 \%$ when stored for $10 \mathrm{~h}$ at room temperature and by $26 \%$ when stored for 7 days in 
the refrigerator $\left(4^{\circ} \mathrm{C}\right)$. Pandrangi and LaBorde (8) studied the effect of storage temperature on retention of folate in commercially packaged fresh spinach and found that only $53 \%$ of folate was retained after 8 days at $4^{\circ} \mathrm{C}$. In contrast, Mullin et al. (9) reported that folate levels in fresh spinach remained unchanged after storage at $4^{\circ} \mathrm{C}$ for 14 days. To the authors' knowledge, only one study has been performed on other green leafy vegetables: Gami and Chen (10) kept Swiss chard at several temperatures and reported folate losses of 30\% after $24 \mathrm{~h}$ at $21^{\circ} \mathrm{C}$ and $12 \%$ after 10 days at $4^{\circ} \mathrm{C}$. However, data on folate content in lettuce stored in regular light for several hours, common in lunchtime restaurants, are not available.

Analysis of folate has been a challenge for a long time because of the large number of structural analogues, their instability and low levels in natural samples. There is no official method for measuring natural folates in foods. The traditionally used microbiological assay does not distinguish between individual forms of folate. High-performance liquid chromatography (HPLC) has to be used. However, a mass detector [i.e. liquid chromatography-mass spectrometry (LC-MS)] may be needed to quantify low levels of different forms of folates in food samples (11).

The aims of this pilot study were to obtain data on the main forms of folate (tetrahydrofolate, 5methyl-tetrahydrofolate and 5-formyl-tetrahydrofolate) in common lettuce varieties and spinach sold in the Nordic countries, to investigate the effect of different storage conditions and preparations in the consumer's home or in lunchtime restaurants, and to detect other forms of folate with an LC-MS method.

\section{Materials and methods}

\section{Sampling of lettuce and spinach}

Fresh whole head lettuce was bought in three different local shops (ICA, Willys and Coop) on one or two occasions. Samples of butterhead lettuce (Lactuca sativa. var. capitata) (130 g), oakleaf lettuce (Lactuca sativa var. crispa) (175 g), frillice lettuce (Cichorium endivia) $(130 \mathrm{~g}+200 \mathrm{~g})$, iceberg (Lactuca sativa var. capitata) $(130 \mathrm{~g}+360 \mathrm{~g})$ and lollo rosso (Lactuca sativa var. crispa) (175 g+ $200 \mathrm{~g}$ ) sold as whole lettuce heads, stored in a plastic carton (PET), plastic wrapping [polypropylene (PP) or polyethylene (PE)] or without any wrapping were collected. Random leaves $(\sim 12 \mathrm{~g}$ each) were ripped off the heads and immediately put in three plastic tubes ( $4 \mathrm{~g}$ each).

Frillice lettuce $(105 \mathrm{~g})$ and romaine lettuce (Lactuca sativa var. longifolia) (100 g) were bought as plants in a pot. Random leaves (12 g) were ripped off the plants and immediately put in three plastic tubes ( $4 \mathrm{~g}$ each).

Frillice lettuce $(60 \mathrm{~g})$, lollo rosso $(40 \mathrm{~g})$, mânche (Valerianella locusta) (60 g), rocket (Eruca sativa) $(60 \mathrm{~g})$ and spinach (Spinacia oleracea) (60 g) were bought as self-service picked salad. Random leaves were picked from each lettuce sample and immediately put in three plastic tubes (4 $\mathrm{g}$ each).

Rocket (175 g) and spinach (150 g) were bought packaged in a modified atmosphere (PET), already rinsed. Random leaves were picked from the bags and immediately put in three plastic tubes $(4 \mathrm{~g}$ each). Rocket (Eruca sativa) $(500 \mathrm{~g}+500 \mathrm{~g})$ was also bought as leaves in a plastic carton (PET). Random leaves were picked from the carton and immediately put in three plastic tubes ( $4 \mathrm{~g}$ each).

All tubes were flushed with nitrogen and immediately stored at $-80^{\circ} \mathrm{C}$.

Two samples of iceberg lettuce (samples no. 1 and 2) were placed on plates at room temperature $\left(22^{\circ} \mathrm{C}\right)$ under regular light for 2 and $4 \mathrm{~h}$. The leaves were either torn into pieces or cut with a smooth-edged knife. Samples of spinach, rocket and frillice lettuce were also placed on plates at room temperature for 2 and $4 \mathrm{~h}$. Random leaves were picked from the plates and immediately put in three plastic tubes (4 g each).

Certified reference material, CRM 485 (lyophilized mixed vegetable), with certified folate content, was obtained from the Institute for Reference Materials and Measurements (Geel, Belgium) and stored as vacuum-packed subsamples $(2 \mathrm{~g})$ at $-80^{\circ} \mathrm{C}$ until analysis.

\section{Reagents and standards}

All chemicals were purchased from Merck (Darmstadt, Germany) unless not otherwise stated. Acetonitrile was of isocratic grade for HPLC. Other chemicals were of analytical quality. Water was purified using a Milli-Q system (Millipore, USA). Thermostable $\alpha$-amylase solution (E-BLAAM, $3000 \mathrm{U} \mathrm{ml}^{-1}$ ) was obtained from Megazyme International (Cork, Republic of Ireland) and used for sample pretreatment without additional preparation. Rat serum (RS) (Scanbur, Sollentuna, Sweden) 
was used as folate conjugase ( $\gamma$-glutamyl hydrolase) source. RS was dialysed to remove endogenous folates as earlier described (12). Protease was purchased from Sigma Chemical Co. (St Louis, MO, USA). Protease solution $\left(5 \mathrm{mg} \mathrm{ml}^{-1}\right)$ was prepared in $10 \mathrm{mmoll}^{-1}$ sodium acetate buffer and dialysed at $4{ }^{\circ} \mathrm{C}$ with stirring in three steps using $800 \mathrm{ml}$ of the $50 \mathrm{mmol}^{-1}$ phosphate buffer $(\mathrm{pH}$ 6.1) containing $0.1 \%(\mathrm{v} / \mathrm{v})$ 2-mercaptoethanol (MCE) in each $40 \mathrm{~min}$ step. The dialysed protease solution was stored at $-20^{\circ} \mathrm{C}$ until use within 2 weeks and the dialysed RS was stored in small portions $(0.5 \mathrm{ml})$ at $-80^{\circ} \mathrm{C}$ and used within 3 months.

Folic acid, (6S)-5-HCO-H 4 folate, sodium salt, (6S)-5- $\mathrm{CH}_{3}-\mathrm{H}_{4}$ folate, sodium salt $(6 \mathrm{R})-5,10-\mathrm{CH}^{+}$$\mathrm{H}_{4}$ folate and $(6 \mathrm{~S})-\mathrm{H}_{4}$ folate, sodium salt, were donated by Eprova AG (Schaffhausen, Switzerland) and 10-HCO-folic acid was obtained from Dr Schirck's Laboratories (Jona, Switzerland). Standard stock solutions of $10-\mathrm{HCO}-\mathrm{H}_{2}$ folate and 5,10$\mathrm{CH}^{+}-\mathrm{H}_{4}$ folate were prepared according to Pfeiffer et al. (1997) (13), while solutions of folic acid, 5$\mathrm{HCO}-\mathrm{H}_{4}$ folate, $10-\mathrm{HCO}-f o l i c$ acid and $5-\mathrm{CH}_{3}-$ $\mathrm{H}_{4}$ folate were prepared as described previously (14). Stock solution of $\mathrm{H}_{4}$ folate $\left(200 \mu \mathrm{g} \mathrm{ml}^{-1}\right.$, purity corrected) was prepared in elution buffer [0.1 M sodium acetate containing $10 \%$ (w/v) $\mathrm{NaCl}$, $1 \%(\mathrm{w} / \mathrm{v})$ ascorbic acid (AA) and $0.1 \%(\mathrm{v} / \mathrm{v}) 2.3-$ dimercapto-1-propanol (BAL) (Sigma-Aldrich, St Louis, MO, USA)]. Aliquots of standard stock solutions were placed in separate tubes, flushed with nitrogen and stored at $-80^{\circ} \mathrm{C}$ for a maximum of 90 days. Calibration solutions were prepared immediately before use by dilution of stock solutions with elution buffer.

\section{Dry matter}

Dry matter of lettuce samples was determined in duplicate according to AOAC method 950.46B (15) at $105-109^{\circ} \mathrm{C}$ for $16.5 \mathrm{~h}$.

\section{Sample preparation}

All samples were extracted in triplicate. Samples were protected against folate oxidation throughout the preparation process by nitrogen, subdued light and cooling on ice after heating. The sample tubes $(4 \mathrm{~g})$ were taken from the freezer $\left(-80^{\circ} \mathrm{C}\right)$ and immediately put in an igloo containing liquid nitrogen. After 1 min the cap was opened and the lettuce sample was crushed with a cooled spatula.
Freshly prepared extraction buffer $[15 \mathrm{ml}$ of $0.1 \mathrm{M}$ phosphate buffer ( $\mathrm{pH}$ 6.1) containing 1\% (w/v) AA and $0.1 \%(\mathrm{v} / \mathrm{v}) \mathrm{BAL}]$ was added to the sample tube. For CRM 485, $0.3 \mathrm{~g}$ lyophilized powder was added to $15 \mathrm{ml}$ in extraction buffer. Samples were extracted, conjugated and centrifuged as described previously (14). For deconjugation of polyglutamate forms of folate, $75 \mu \mathrm{l} \mathrm{RS}$ was added to $3.2 \mathrm{ml}$ supernatant. To evaluate the effect of dienzyme and trienzyme treatment, rocket samples, in triplicate, were also prepared with $40 \mu 1 \alpha$-amylase during the extraction step and incubation with $1 \mathrm{ml}$ protease solution for $1.5 \mathrm{~h}$ at $37^{\circ} \mathrm{C}$ followed by 5 min deactivation by boiling before the deconjugation step.

All prepared extracts were frozen below $-20^{\circ} \mathrm{C}$ before sample clean-up. Blank samples containing the enzyme suspensions were prepared and treated in the same way as the lettuce samples for corrections of endogenous folate. Before quantification, extracts were purified by solid-phase extraction (SPE) on strong anion exchange (SAX) Isolute cartridges $(500 \mathrm{mg}$; International Sorbent Technology, Mid-Glamorgan, UK). Aliquots $(2.5 \mathrm{ml})$ of extract were applied to the preconditioned cartridges and eluted with freshly prepared elution buffer (prepared as described in Reagents and standards $)$. The first portion $(0.5 \mathrm{ml})$ of eluate was discarded and the second portion $(3.5 \mathrm{ml})$ was weighed and collected for HPLC analysis. To eliminate interference more effectively, a combination with PH EC cartridges prior to the SAX sorbents was also investigated, as described previously (16).

Recovery tests were performed by adding known amounts of $\mathrm{H}_{4}$ folate and $5-\mathrm{CH}_{3}-\mathrm{H}_{4}$ folate at two levels to a spinach sample in triplicate before extraction. The repeatability of the analytical procedure was checked by always including a certified reference material CRM 485 sample on each extraction day.

\section{High-performance liquid chromatography}

Quantification by HPLC was performed on an Agilent 1100 system as described previously (12). The folates were separated on a Thermo ElectronCorporation Aquasil $\mathrm{C}_{18}$ column $(3 \mu \mathrm{m}, 150 \times$ $4.6 \mathrm{~mm}$ ) with a $\mathrm{C}_{18}(1 \mathrm{~mm})$ guard column (Optimize Technologies). The chromatographic conditions for gradient elution were as follows: column temperature, $23^{\circ} \mathrm{C}$; autosampler temperature, $8^{\circ} \mathrm{C}$, flow rate 
$0.4 \mathrm{ml} \mathrm{min}{ }^{-1}$; volume injected, $20 \mu \mathrm{l}$; fluorescence detection (FD), $290 \mathrm{~nm}$ excitation and $360 \mathrm{~nm}$ emission; ultraviolet (UV) detection, 280, 290 and $300 \mathrm{~nm}$. The mobile phase consisted of $30 \mathrm{mM}$ potassium phosphate buffer ( $\mathrm{pH} 2.3$ ), using a gradient with acetonitrile starting at $6 \%(\mathrm{v} / \mathrm{v})$ which was maintained isocratically for the first $5 \mathrm{~min}$; thereafter, the acetonitrile concentration was increased linearly to $25 \%$ within 20 min and the total run time was $42 \mathrm{~min}$. Peaks were identified by retention times and identity was confirmed by comparing ratios of fluorescence and UV peak heights (h) at different wavelengths; in addition, fluorescence and diode array spectra were used to verify individual folates. Quantification was based on an external standard method. The peak area was plotted against concentration and least-square regression analysis was used to fit lines to the data. A multilevel calibration curve was used $(n=7)$ and the amount of each form of folate was calculated in its free acid form. Total folate was calculated as the sum of $\mathrm{H}_{4}$ folate, $5-\mathrm{CH}_{3}-\mathrm{H}_{4}$ folate and 5- $\mathrm{HCO}-\mathrm{H}_{4}$ folate, expressed as folic acid equivalents (MW, 441.4) considering different molecular weights for the three native folate forms.

\section{Liquid chromatography-mass spectrometry}

To investigate further forms of folates in the lettuce samples, seven of the sample extracts were analysed on an LC-MS single quadrupole system (Agilent 1100 series) using an in-house optimized and validated method (17). The column (Ace $\mathrm{C}_{18}$, $150 \mathrm{~mm} \times 4.6 \mathrm{~mm}, 3 \mu \mathrm{m}$; Advanced Chromatography Technologies, Aberdeen, UK) was used for separation. The flow rate was $0.3 \mathrm{ml} \mathrm{min}{ }^{-1}$, the injection volume was $20 \mu \mathrm{l}$ and the mobile phase used was acetonitrile-methanol $(6 \%)$ and $0.01 \mathrm{M}$ acetic acid, under linear gradient elution conditions. Electrospray ionization was operated in positive ion mode. Fragmentor potential was set to $100 \mathrm{~V}$ for all forms of folates. For quantification of folates selected ion monitoring of protonated molecular ions $[\mathrm{M}+\mathrm{H}]^{+}$was used at $\mathrm{m} / \mathrm{z} 460$ for $5-\mathrm{CH}_{3}-\mathrm{H}_{4}$ folate, $\mathrm{m} / \mathrm{z} 442$ for folic acid, $\mathrm{m} / \mathrm{z} 472$ for $10-\mathrm{HCO}-\mathrm{H}_{2}$ folate, $\mathrm{m} / z \quad 474$ for $5-\mathrm{HCO}-\mathrm{H}_{4}$ folate, $\mathrm{m} / \mathrm{z} 470$ for 10 -HCO-folic acid, $\mathrm{m} / \mathrm{z} 446$ for $\mathrm{H}_{4}$ folate and $m / z 457$ for $5,10-\mathrm{CH}^{+}-\mathrm{H}_{4}$ folate. Mass spectral data as well as retention times of compounds were used for peak identification and quantification was based on an external standard method $(n=8)$.
Statistical analysis and calculation of nutrient retention The results are presented as mean values from triplicates, except for the results of the LC-MS analysis, where single values are presented. Statistical analysis were performed with Tukey's pairwise comparison $(\alpha=0.05)$ using Minitab software, release 14 (Minitab, Coventry, UK) and significant differences were considered from $p<0.05$.

\section{Results and discussion}

\section{Folates in leafy vegetables}

The folate content and forms of eight different lettuce varieties and spinach based on LC-FD analyses are presented in Table 1. The lettuce varieties were purchased in three local shops, originated from six European countries and were sold with different kinds of wrapping as described in Materials and methods and Table 1 . The total folate concentration expressed in folic acid equivalents and calculated from the sum of $\mathrm{H}_{4}$ folate, $5-\mathrm{CH}_{3}-$ $\mathrm{H}_{4}$ folate and $5-\mathrm{HCO}-\mathrm{H}_{4}$ folate varied from 30 to $198 \mu \mathrm{g} 100 \mathrm{~g}^{-1}$ on a fresh weight (FW) basis. Spinach contained in total $172-177 \mu \mathrm{g} 100 \mathrm{~g}^{-1}$ FW. The three rocket samples showed a large variation in the total folate concentrations (108,

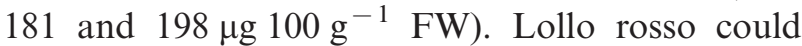
also be considered as a good folate source since all three samples contained total folate concentrations above $90 \mu \mathrm{g} 100 \mathrm{~g}^{-1} \mathrm{FW}\left(90-125 \mu \mathrm{g} 100 \mathrm{~g}^{-1} \mathrm{FW}\right)$. In contrast, the popular iceberg lettuce contained only 30,38 and $43 \mu \mathrm{g}$ total folate $100 \mathrm{~g}^{-1} \mathrm{FW}$ in the three samples analysed. Frillice lettuce $(48-112 \mu \mathrm{g}$ $\left.100 \mathrm{~g}^{-1} \mathrm{FW}\right)$, romaine lettuce (56 $\left.\mu \mathrm{g} 100 \mathrm{~g}^{-1} \mathrm{FW}\right)$, butterhead lettuce $\left(71 \mu \mathrm{g} 100 \mathrm{~g}^{-1} \mathrm{FW}\right)$ and oakleaf

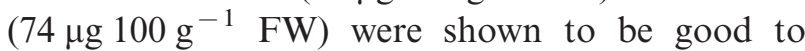
moderate folate sources.

Three different forms of folate were separated and quantified by LC-FD. The major form of folate was $5-\mathrm{CH}_{3}-\mathrm{H}_{4}$ folate, followed by $5-\mathrm{HCO}$ $\mathrm{H}_{4}$ folate and $\mathrm{H}_{4}$ folate, but their relative proportions varied between cultivars and within varieties. The most labile form, $\mathrm{H}_{4}$ folate, for self-service picked spinach was only half that of spinach packaged in a modified atmosphere, which could be expected since $\mathrm{H}_{4}$ folate is susceptible to oxidative degradation. The degradation of $\mathrm{H}_{4}$ folate could also be observed when comparing selfservice picked rocket with rocket packed in a modified atmosphere. However, it is difficult to draw any conclusions on the preferred packing 
method. A reasonable explanation is that not only did the method of packaging differ between samples belonging to the same leafy vegetable cultivar, but also that they originated from batches that differed in cultivation conditions, harvest and postharvest conditions. More experiments with several lettuce samples from each packing method are needed to be able to draw significant conclusions.

\section{Folate retention during storage}

One sample (in triplicate) each of self-service picked frillice lettuce and of self-service picked spinach was selected to investigate the retention of folates when stored at room temperature $\left(22^{\circ} \mathrm{C}\right)$ and in regular light on a plate for 2 or $4 \mathrm{~h}$ to simulate the condition in lunchtime restaurants. One sample of rocket sold in a plastic carton was also chosen for this study and lettuce from that sample was also placed in the refrigerator $\left(4^{\circ} \mathrm{C}\right)$ for 8 days, stored in its original plastic carton.

The total folate content (folic acid equivalents) was reduced by $14-40 \%$ on a dry matter basis in all the stored lettuce samples. As shown in Fig. 1, frillice lettuce showed a significant $(p<0.05)$ reduc- tion of $40 \%$ in total folates after $4 \mathrm{~h}$. The rocket purchased in a plastic carton also lost significant $(p<0.05)$ amounts $(22 \%)$ of total folates after $4 \mathrm{~h}$ at $22^{\circ} \mathrm{C}$. In the refrigerator, $14 \%$ of the total folates in rocket were lost. This reduction, however, was not significant $(p>0.05)$. Spinach already showed a significant $(p<0.05)$ reduction of $30 \%$ in total folate content after $2 \mathrm{~h}$ in room temperature. Given the minor changes in moisture content $(<1 \%$ in all processes), folate losses in the stored samples were due to degradation of folate.

As shown in Fig. 2, the content of total folates in two different iceberg lettuce heads (nos 1 and 2) was well retained in iceberg lettuce pieces torn or cut from the heads and stored for $2 \mathrm{~h}$. After $4 \mathrm{~h}, 23 \%$ of the total folate content was lost in the pieces that were torn from the lettuce head (no. 2) and $36 \%$ of the total folates in the pieces cut from the head (no. 2). However, only the reduction in the lettuce pieces cut with a knife from the iceberg head was significant $(p<0.05)$. In the refrigerator $14 \%$ of total folate was lost after 8 days' storage, a non-significant change, which is similar to the $12 \%$ losses of total folates reported in Swiss chard after 10 days (10).

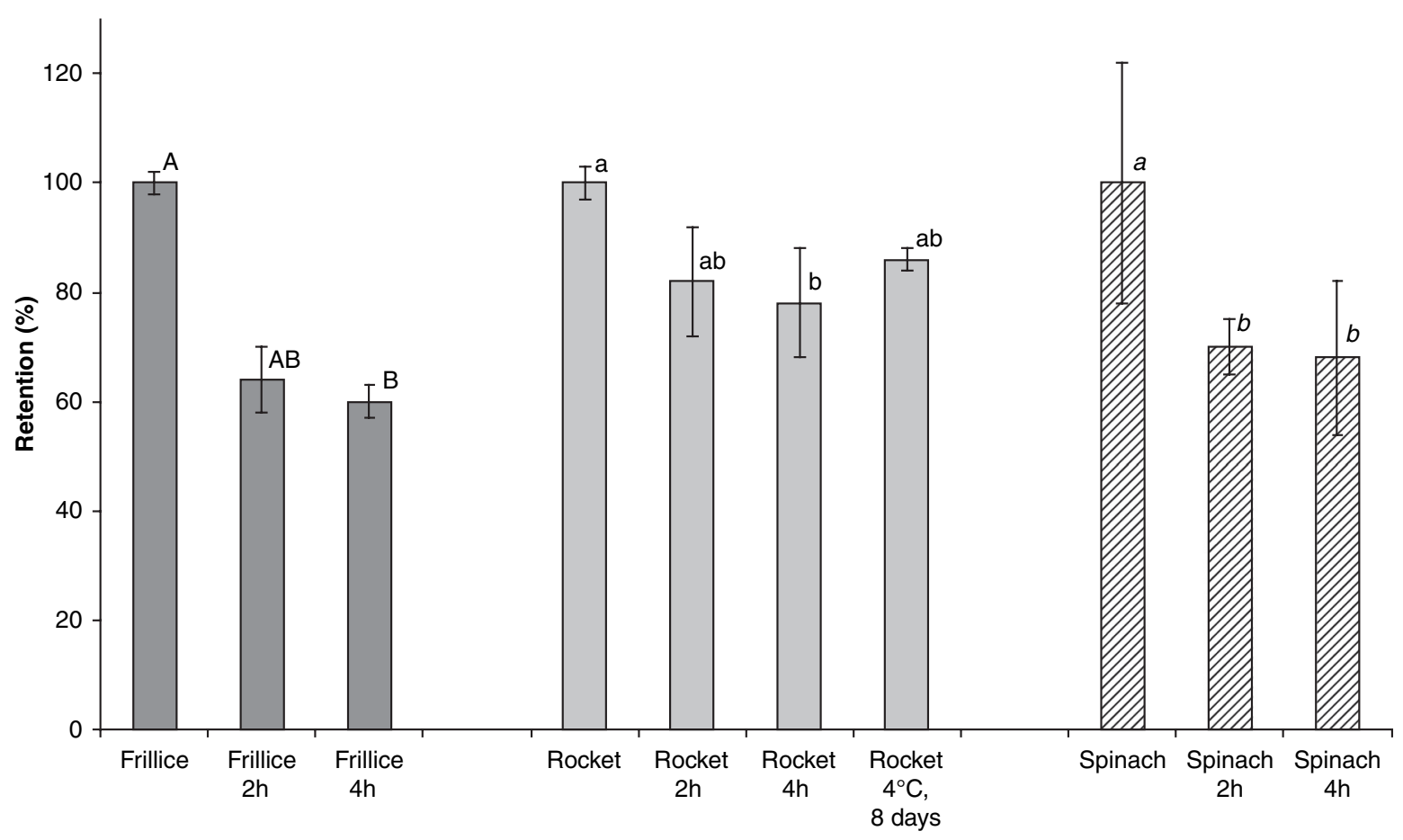

Fig. 1. (\%) of total folates in rocket, frillice lettuce and spinach on a dry matter basis when stored on a plate in regular light for 2 or $4 \mathrm{~h}$ at $22{ }^{\circ} \mathrm{C}$. Leaves from frillice were also stored in the refrigerator $\left(4^{\circ} \mathrm{C}\right)$ for 8 days. Values are means $\pm \mathrm{SD}$ (for three replicates) as shown by vertical bars. Different letters show statistically significant $(p<0.05)$ differences in folate content after different storage conditions compared with the product directly after purchase. 


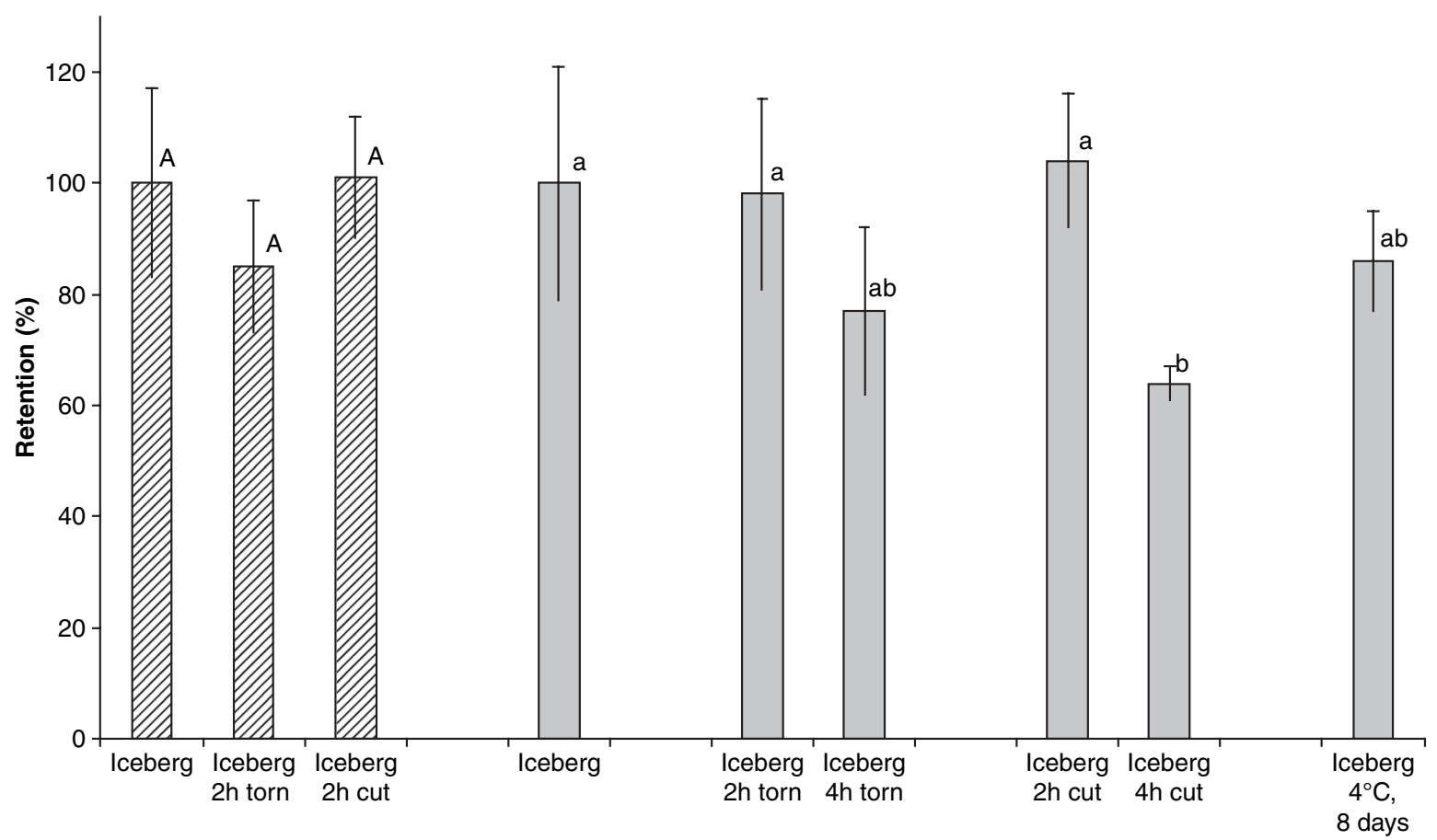

Fig. 2. (\%) of total folates (calculated on a dry matter basis) in two different samples (no. 1, striped and no. 2, shaded) of torn or cut iceberg lettuce stored on a plate in regular light for 2 and $4 \mathrm{~h}$ at $22^{\circ} \mathrm{C}$, respectively, compared with whole heads. Leaves from one lettuce head (no. 2) were stored in the refrigerator $\left(4^{\circ} \mathrm{C}\right)$ for 8 days. Values are means $\pm \mathrm{SD}$ (for three replicates) as shown by vertical bars. Different letters show statistically significant $(p<0.05)$ differences in folate content after different storage conditions compared with the product directly after purchase.

Methodological comparisons and quality assurance of folate analysis

In the present study, LC-MS was used as a quantification method to confirm the forms of folate found in the leafy vegetables analysed. 5$\mathrm{CH}_{3}-\mathrm{H}_{4}$ folate and 5-HCO- $\mathrm{H}_{4}$ folate were detected in all leafy vegetables with both LC-FD and LC-MS. $\mathrm{H}_{4}$ folate was found in all samples using LC-FD, but only in small amounts in iceberg lettuce

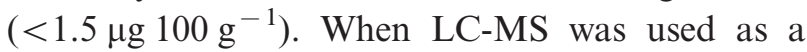
quantification method no $\mathrm{H}_{4}$ folate was detected in iceberg lettuce or rocket, but data were similar for the three forms of folate $\left(\mathrm{H}_{4}\right.$ folate, $5-\mathrm{CH}_{3}-\mathrm{H}_{4}$ folate and $5-\mathrm{HCO}-\mathrm{H}_{4}$ folate) when analysed by either LCFD or LC-MS (Fig. 3). The LC-MS method also detected 10-HCO-folic acid in four out of the seven lettuce samples analysed, whereas $10-\mathrm{HCO}-\mathrm{H}_{2}$ folate and $5,10-\mathrm{CH}^{+}-\mathrm{H}_{4}$ folate were not detected in any of the samples.

The LC-MS data indicated that formyl forms of folate are the dominant form of folate in all lettuce varieties except for iceberg lettuce. This was not as consistent when using LC-FD as the quantification method (Table 1). Formyl folates in leafy vegetables analysed by LC-FD or LC-MS-MS have been reported previously $(11,18,19)$, but not as the dominant form as seen in this study. Therefore, further analyses with LC-MS or LC-MS-MS are needed to confirm these results.

Previously published data on folate content based on microbiological assay are of the same magnitude as the present total folate data obtained with LCFD or LC-MS. The few comparative data found on folate concentrations in the literature based on LCFD or LC-MS-MS are also in similar ranges. Thus, Konings et al. (19) reported a total folate content of $42 \mu \mathrm{g} 100 \mathrm{~g}^{-1}$ in iceberg lettuce using an LC-FD method. In the Nordic food tables the total folate values in iceberg lettuce are reported to be $56 \mu \mathrm{g} 100 \mathrm{~g}^{-1}$ (20), $53 \mu \mathrm{g} 100 \mathrm{~g}^{-1}$ (21) and $89 \mu \mathrm{g}$ $100 \mathrm{~g}^{-1}$ (21), respectively, all analysed with the traditional microbiological assay.

One of the critical steps in folate analyses is sample preparation, e.g. heat extraction, combined with different enzyme treatments to release efficiently all folates from the food matrix. In the present study, folates were extracted from the food matrix using $0.1 \mathrm{M}$ phosphate buffer with added antioxidants (ascorbic acid and BAL). BAL was chosen as an antioxidant since it has been shown to 


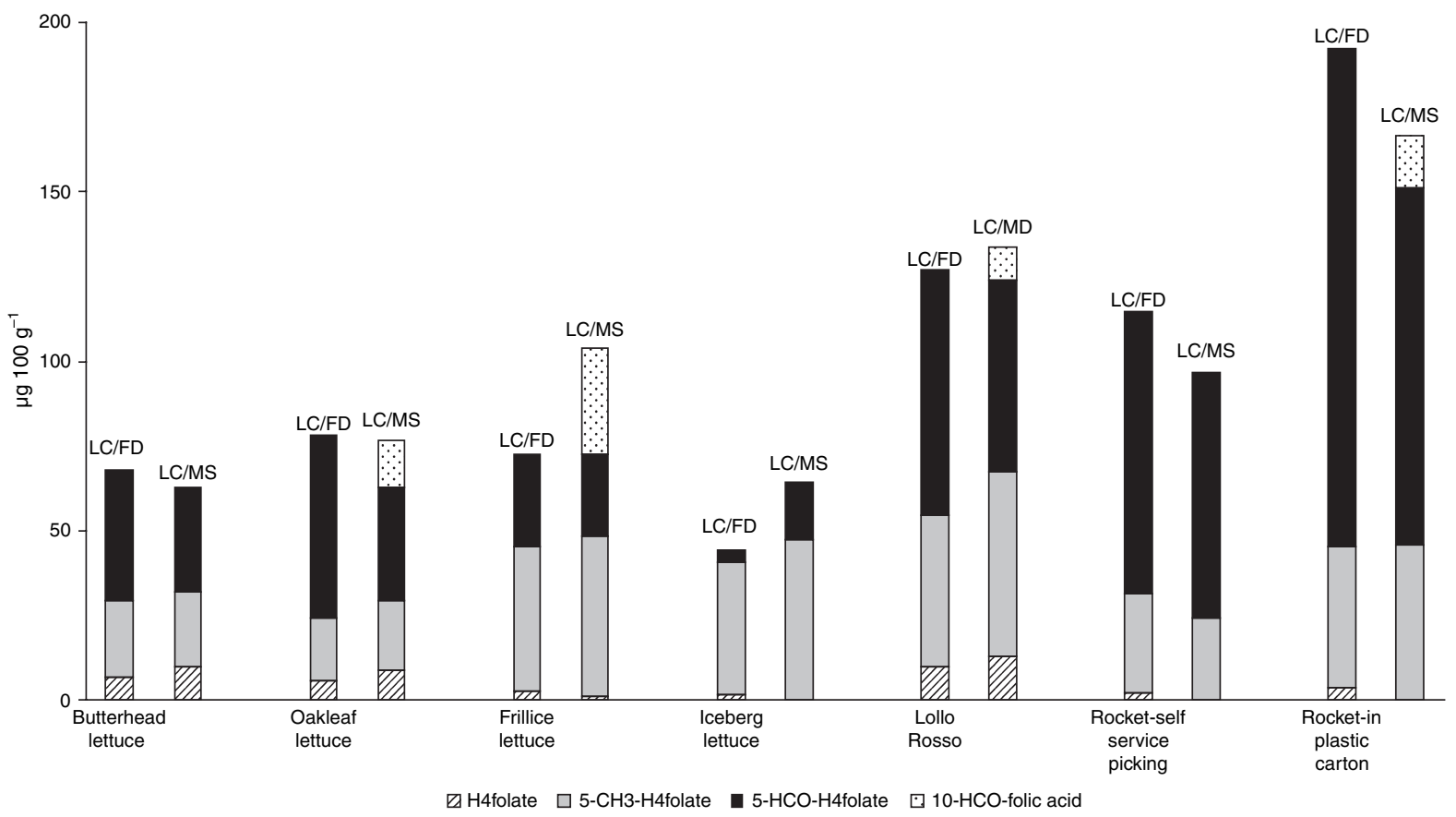

Fig. 3. Comparisons between the distribution of different forms of folate in seven different varieties of lettuce when quantified with liquid chromatography with fluorescence detector (LC-FD) $(n=3)$ and liquid chromatography with mass spectrometer detector (LC-MS) $(n=1)$.

Table $I$. Mean content of individual and total folate $\left(\mu \mathrm{g} 100 \mathrm{~g}^{-1}\right)$ in several lettuce varieties and spinach on a fresh weight basis ${ }^{\mathrm{a}}$

\begin{tabular}{|c|c|c|c|c|c|c|}
\hline Name & Description & Country of origin & 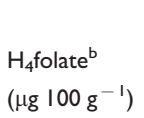 & $\begin{array}{l}5-\mathrm{CH}_{3}-\mathrm{H}_{4} \text { folate }^{\mathrm{c}} \\
\left(\mu \mathrm{g} 100 \mathrm{~g}^{-1}\right)\end{array}$ & $\begin{array}{l}5-\mathrm{HCO}-\mathrm{H}_{4} \text { folate }^{\mathrm{d}} \\
\left(\mu \mathrm{g} \mathrm{l} 00 \mathrm{~g}^{-\mathrm{I}}\right)\end{array}$ & $\begin{array}{l}\text { Total folate }^{\mathrm{e}} \\
\text { (folic acid equivalents) } \\
\left(\mu \mathrm{g} 100 \mathrm{~g}^{-1}\right)\end{array}$ \\
\hline Butterhead lettuce $^{f}$ & Whole head, not packed & Sweden & $7.0 \pm 3.7$ & $22.3 \pm 2.5$ & $38.7 \pm 13$ & $70.8 \pm 7.5$ \\
\hline Frillice lettuce ${ }^{g}$ & As a plant & Sweden & $6.3 \pm 3.2$ & $32.3 \pm 9.1$ & $11.2 \pm 5.7$ & $47.8 \pm 3.4$ \\
\hline Frillice lettuce ${ }^{f}$ & Whole head in plastic carton & Sweden & $2.5 \pm 2.1$ & $42.7 \pm 6.1$ & $27.5 \pm 2.3$ & $69.4 \pm 2.3$ \\
\hline Frillice lettuce $^{\mathrm{h}}$ & In plastic bags & Denmark & $3.6 \pm 3.5$ & $68.5 \pm 3.8$ & $7.3 \pm 2.7$ & $72.8 \pm 3.1$ \\
\hline Frillice lettuce ${ }^{f}$ & Self-service picked salad & Sweden & $9.3 \pm 2.0$ & $65.5 \pm 1.0$ & $42.2 \pm 20$ & $|12 \pm 2|$ \\
\hline Iceberg $^{f}$ & Whole head in plastic bag & Germany & $1.2 \pm 0.0$ & $26.8 \pm 1.9$ & $2.9 \pm 1.2$ & $29.7 \pm 0.6$ \\
\hline Iceberg $^{f}$ & Whole head in plastic wrapping & Spain & $0.2 \pm 0.1$ & $34.7 \pm 3.2$ & $7.5 \pm 0.4$ & $38.2 \pm 7.1$ \\
\hline Iceberg ${ }^{h}$ & Whole head in plastic wrapping & Germany & $1.5 \pm 0.4$ & $39.1 \pm 7.6$ & $3.8 \pm 3.3$ & $42.7 \pm 9.0$ \\
\hline Lollo rosso ${ }^{f}$ & In plastic carton & France & $5.3 \pm 1.1$ & $38.8 \pm 1.1$ & $51 \pm 1.5$ & $90.5 \pm 1.5$ \\
\hline Lollo rosso ${ }^{f}$ & Self-service picked salad & Sweden & $9.6 \pm 1.4$ & $54.2 \pm 3.6$ & $42.0 \pm 12$ & $101 \pm 8.2$ \\
\hline Lollo rosso ${ }^{h}$ & In plastic bags & Denmark & $9.7 \pm 3.7$ & $44.9 \pm 17$ & $72.2 \pm 17$ & $125 \pm 22$ \\
\hline Manche $^{f}$ & Self-service picked salad & France & $6.4 \pm 1.7$ & $41.9 \pm 1.9$ & $72.0 \pm 13$ & $114 \pm 9.5$ \\
\hline Oakleaf lettuce ${ }^{f}$ & In plastic carton & Sweden & $5.6 \pm 2.7$ & $18.7 \pm 4.1$ & $54.0 \pm 19$ & $74.2 \pm 13$ \\
\hline Rocket $^{g}$ & Self-service picked salad & Italy & $2.0 \pm 0.3$ & $29.5 \pm 0.7$ & $83.0 \pm 12$ & $108 \pm 15$ \\
\hline Rocket $^{f}$ & In plastic carton & Italy & $3.5 \pm 2.8$ & $41.7 \pm 6.7$ & $147 \pm 1.4$ & $181 \pm 9.7$ \\
\hline Rocket $^{\text {g }}$ & In protective atmosphere; rinsed & Unknown & $2.8 \pm 3.8$ & $54.0 \pm 8.1$ & $152 \pm 7.5$ & $198 \pm 17$ \\
\hline Romaine lettuce $^{f}$ & As a plant & Sweden & $2.9 \pm 1.3$ & $39.4 \pm 8.8$ & $21.9 \pm 9.9$ & $56.6 \pm 13$ \\
\hline Spinach $^{g}$ & In protective atmosphere; rinsed & Unknown & $28.1 \pm 3.8$ & $101 \pm 34$ & $51.1 \pm 1.7$ & $172 \pm 29$ \\
\hline Spinach $^{f}$ & Free-choice delicatessen salad & Italy & $14.5 \pm 6.5$ & $95.1 \pm 24$ & $76.1 \pm 22$ & $177 \pm 34$ \\
\hline
\end{tabular}

Folates were analysed by liquid chromatography-fluorescence detection (LC-FD).

${ }^{a}$ All folate results are means of triplicates $\pm \mathrm{SD} ;{ }^{b} \mathrm{H}_{4}$ folate $=$ tetrahydrofolate; ${ }^{\mathrm{c}} 5-\mathrm{CH}_{3}-\mathrm{H}_{4}$ folate $=5$-methyl-tetrahydrofolate; ${ }^{\mathrm{d}} 5$ - $\mathrm{HCO}$ - $\mathrm{H}_{4}$ folate $=5$-formyl-tetrahydrofolate; ${ }^{e}$ total folate $=$ measured as the sum of $\mathrm{H}_{4}$ folate, $5-\mathrm{CH}_{3}-\mathrm{H}_{4}$ folate, $5-\mathrm{HCO}-\mathrm{H}_{4}$ folate, expressed as folic acid equivalents; ${ }^{\mathrm{f}} \mathrm{g}, \mathrm{h}$ samples purchased at three different shops: ICA, Coop and Willys, respectively. 
be the best stabilizer of the most labile form of folate, $\mathrm{H}_{4}$ folate, in phosphate buffer (23). To improve folate extraction from the food matrix and simultaneously stabilize the folates, liquid nitrogen was used to homogenize the lettuce samples efficiently and gently before heat extraction and enzyme treatments, as previously reported (11). Monoenzyme treatment with rat serum conjugase was chosen since lettuce and spinach are known to contain negligible amounts of starch and protein and have previously been shown not to require amylase and protease treatment $(19,24)$.

\section{Conclusions}

Data on the concentration of individual forms of folates $\left(\mathrm{H}_{4}\right.$ folate, $5-\mathrm{CH}_{3}-\mathrm{H}_{4}$ folate and $5-\mathrm{HCO}-\mathrm{H}_{4}$ folate) were obtained for eight different lettuce varieties and spinach sold in different wrappings and as whole lettuce heads or loose leaves. The forms of folates were, in decreasing proportions: formylated reduced folates $>$ methylated reduced folates $>$ tetrahydrofolate. These results are in contrast to previous reported results, where methylated reduced folates were dominant $(11,18,19)$. This study clearly indicated the need for a mass spectrometry detector to quantify and characterize all forms of folate. Further studies on folate quantification in foods should use optimized and validated sample preparation combined with LC-MS or LCMS-MS analysis.

Storage of torn or cut fresh lettuce for up to $2 \mathrm{~h}$ in room temperature or for 8 days in a refrigerator caused no significant folate losses. After $4 \mathrm{~h}$ at room temperature folate was significantly decreased in spinach, rocket and frillice lettuce. Spinach lost significant amounts of folate after $2 \mathrm{~h}$ at room temperature.

The total folate content in the lettuce samples varied from 30 to $198 \mu \mathrm{g} 100 \mathrm{~g}^{-1}$ on a fresh weight basis; rocket contained total folate concentrations above $100 \mu \mathrm{g} 100 \mathrm{~g}^{-1}$, while iceberg contained only $30-43 \mu \mathrm{g}$ total folate $100 \mathrm{~g}^{-1}$. These figures are within the ranges reported previously $(19,20,25)$. The six-fold variation in total folate content between various lettuce varieties in this pilot study argues for a replacement of the most popular iceberg lettuce with varieties higher in folate, e.g. lollo rosso and rocket. Further analyses with optimized and validated LC-MS or LC-MS-MS analyses are needed to obtain more representative data on total folate content and forms in lettuce and other leafy vegetables.

\section{Acknowledgements}

The gift of folate standards from Eprova AG Schaffhausen is gratefully acknowledged. Special thanks to Christina Nilsson, Division of Meat Science, Department of Food Science, SLU, for assistance with the liquid nitrogen. We also thank the folate group, especially Veronica Öhrvik and Johan Patring at the Division of Food Chemistry, Department of Food Science, SLU, for valuable support with the methodology.

\section{References}

1. Similä M, Fagt S, Vaask S, Thorgeirsdottir H, Padule I, Petkeviciene J, et al. The NORBAGREEN 2002 study. Copenhagen: Nordic Council of Ministers; 2003.

2. Anon. WHO TRS 916. Diet, nutrition and the prevention of chronic diseases. Report from a joint FAO/WHO Expert Consultation. Geneva: World Health Organization; 2003.

3. NNR, Nordic Nutrition Recommendations 2004, Nord 2004:13, 4th edn. Copenhagen: Nordic Council of Ministers; 2004.

4. Bailey LB, Rampersaud GC, Kauwell GPA. Folic acid supplements and fortification affect the risk for neural tube defects, vascular disease and cancer: evolving science. J Nutr 2003; 133: 1961-8S.

5. Boushey CJ, Beresford SA, Omenn GS, Motulsky AG. A quantitative assessment of plasma homocysteine as a risk factor for vascular disease. JAMA 1995; 274: 104957.

6. de Bree A, van Dusseldorp M, Brouwer IA, van het Hof $\mathrm{KH}$, Steegers-Theunissen RPM. Folate intake in Europe: recommended, actual and desired intake. Eur J Clin Nutr 1997; 51: 643-60.

7. Chen T-S, Song Y-O, Kirsch AJ. Effects of blanching, freezing and storage on folacin contents of spinach. Nutr Rep Int 1983; 28: 317-23.

8. Pandrangi S, LaBorde LF. Retention of folate, carotenoids, and other quality characteristics in commercially packaged fresh spinach. J Food Sci 2004; 69: C702-7.

9. Mullin WJ, Wood DF, Howsam SG. Some factors affecting folacin content of spinach, Swiss chard, broccoli and brussels sprouts. Nutr Rep Int 1982; 26: $7-16$.

10. Gami DB, Chen T-S. Kinetics of folacin destruction in Swiss chard during storage. J Food Sci 1985; 50: 447-9.

11. Zhang GF, Storozhenko S, van der Straeten D, Lambert WE. Investigation of the extraction behaviour of the main monoglutamate folates from spinach by liquid chromatography-electrospray ionization tandem mass spectrometry. J Chromatogr A 2005; 1078: 59-66.

12. Patring JDM, Jastrebova JA, Hjortmo SB, Andlid T, Jägerstad MI. Development of a simplified method for simultaneous determination of folates in bakers' yeast 
by liquid chromatography with ultraviolet and fluorescence detection. J Agric Food Chem 2005; 53: 2406-11.

13. Pfeiffer CM, Rogers LM, Bailey LB, Gregory JF. Absorption of folate from fortified cereal-grain products and of supplemental folate consumed with or without food determined using a dual-label stable-isotope protocol. Am J Clin Nutr 1997; 66: 1388-97.

14. Holte Stea T, Johansson M, Jägerstad M, Frølich W. Retention of folates in cooked, stored and reheated peas, broccoli and potatoes for use in modern large-scale service systems. Food Chem 2006; 101: 1095-107.

15. AOAC. Official methods of analysis. In: Horwitz W, ed. AOAC official method 992.05 folic acid (pteroylglutamic acid) in infant formula. Vol 2. 17th ed. Gaithersburg, MD: AOAC International; 2000:50.024-50.6.

16. Nilsson C, Johansson M, Yazynina E, Strålsjö L, Jastrebova J. Solid-phase extraction for HPLC analysis of dietary folates. Eur Food Res Technol 2004; 219: 199-204.

17. Patring JDH, Jastrebova JA. Application of liquid chromatography - electrospray ionisation mass spectrometry for determination of dietary folates: Effects of buffer nature and mobile phase composition on sensitivity and selectivity. J Chromatogr A 2007; 1143: 72-82.

18. Freisleben A, Schieberle P, Rychlik M. Specific and sensitive quantification of folate vitamers in foods by stable isotope dilution assays using high-performance liquid chromatography-tandem mass spectrometry. Anal Bioanal Chem 2003; 376: 149-56.

19. Konings EJ, Roomans HH, Dorant E, Goldbohm RA, Saris WH, van den Brandt PA. Folate intake of the Dutch population according to newly established liquid chromatography data for foods. Am J Clin Nutr 2001; 73: 765-76.

20. SLV. Food composition table - energy and nutrients. Uppsala: SLV; 2002.

21. Fineli. Finnish food composition database. Helsinki: Finnish Public Health Institute, Nutrition Unit; 2004.

22. Møller A, Saxholt E, Christensen AT, Hartkopp HB, Hess Ygil K. Danish food composition databank, revision 6.0. Department of Nutrition, Danish Institute for Food and Veterinary Research; 2005 (http:// www.foodcomp.dk/:Food Informatics).

23. Patring JDM, Johansson MS, Yazynina E, Jastrebova JA. Evaluation of impact of different antioxidants on stability of dietary folates during food sample preparation and storage of extracts prior to analysis. Anal Chim Acta 2005; 553: 36-42.

24. Shrestha AK, Arcot J, Paterson J. Folate assay of food by traditional and tri-enzyme treatments using cryoprotected Lactobacillus casei. Food Chem 2000; 71: 54552.

25. Simonne A, Simonne E, Eitenmiller R, Coker $\mathrm{CH}$. Bitterness and composition of lettuce varieties grown in the southeastern United States. Horttechnology 2002; 12: $721-6$.

\section{Wenche Frølich}

Norwegian School of Hotel Management

University of Stavanger

NO-4036 Stavanger

Norway

E-mail: wenche.frolich@uis.no 